\title{
OLIVEIRA, Ricardo Costa de. Na teia do nepotismo - sociologia política das relações de parentesco e poder político no Paraná e no Brasil. Curitiba: Editora Insight, 2012. 271 p.
}

\section{Tiago Valenciano ${ }^{1}$}

- Enviado em 12/08/2015

- Aprovado em 18/09/2015

“A minha tese é simples. Família ainda importa. As estruturas de parentesco formaram parte da realidade social e política brasileira no século XXI". Com esta afirmação, Ricardo Costa de Oliveira dá início às discussões sobre um dos temas da moda na sociologia política brasileira: o nepotismo. Em "Na teia do nepotismo - sociologia política das relações de parentesco e poder político no Paraná e no Brasil", Oliveira pretende traçar um panorama geral sobre como o nepotismo surgiu, se desenvolveu e ainda perpetua nas diversas esferas de poder no país. De leitura agradável e contendo uma gama valorosa de dados, o livro pode nos apontar realidades não conhecidas sobre a temática, além de indicar novos "achados e horizontes" de pesquisa face ao relevante banco de dados presente no mesmo.

Apesar de haver uma divisão do livro em alguns capítulos - ainda que não estejam indicados expressamente, podemos apontar que são cinco as vertentes de trabalho do autor: a) as origens do nepotismo e o início do fenômeno no Brasil; b) a valorização da estrutura social e da genealogia do nepotismo; c) as diversas redes de nepotismo; d) o panorama do nepotismo no Estado do Paraná; e) como 62 famílias comandam o poder paranaense na contemporaneidade.

No decorrer deste exame, Ricardo Costa de Oliveira aponta que o nepotismo aproveita-se da fragilidade das instituições políticas, aliado às desigualdades sociais presentes no Brasil, à

\footnotetext{
${ }^{1}$ Graduado em Ciências Sociais pela Universidade Estadual de Maringá (UEM) e Mestre pela mesma instituição. Doutorando em Sociologia pela Universidade Federal do Paraná (UFPR). Membro do Núcleo de Estudos Paranaenses (NEP). Endereço eletrônico: tiagovalenciano@gmail.com
} 
patronagem e ao clientelismo político. Esta tríade, portanto, é um prato cheio para que o fenômeno se desenvolva na forma de um sistema político próprio, de uma estratégia de classes e de famílias para a conquista, manutenção e exercício do poder pelas redes do nepotismo amplamente trabalhadas no texto.

Deste modo, a hierarquização do Estado brasileiro em seu princípio (pautado também por insígnias simbólicas) aliado à nobreza portuguesa contribui para que o nepotismo se desenvolvesse. Afinal, o poder nas câmaras municipais, dos padres das famílias e dos tabelionatos era geralmente concentrado nas mãos de poucas famílias. Além disso, frequentar espaços sociais comuns e o relacionamento intraclasse fizeram com que a miscigenação entre as famílias aumentasse nas vilas do país. Em outras palavras: os integrantes da nobreza procuravam perpetuar os laços familiares com membros de famílias da mesma linhagem social, postadas sempre nos altos estratos sociais. Estas foram as linhas gerais das origens do nepotismo no Brasil, descritas minuciosamente pelo autor, com citação de dados históricos e episódios que marcaram o início do domínio das famílias nas esferas de poder nacionais.

No segundo momento, há a valorização da estrutura social e os indícios de como o nepotismo se transformou em um processo condizente com a sociedade brasileira. Neste sentido, o autor argumenta que as famílias de origem portuguesa - chamadas de "quinhentões" são as que dominam as estruturas de poder, espalhando-se pelos principais postos de ação social. Prova disso são as propriedades escravistas em seus nomes, a atuação nas fazendas e nos engenhos, os proprietários de tabelionatos, representação de autoridade nas vilas, a extensão para os poderes legislativo, executivo e judiciário, enfim, uma ramificação socioestatal e Estado e sociedade amplamente difundida até os dias de hoje. Aliada a esta estrutura social brasileira surge a análise genealógica, ratificando a tese de Oliveira que família ainda importa: o Estado em que os poderosos mandam necessita de pesquisas sobre a genealogia e as redes de parentesco atuando em favor do poder.

Diante deste quadro, o nepotismo e seus tentáculos é, sobretudo, "um processo de produção e reprodução de desigualdades" e, segundo Oliveira, é necessária a criação de um observatório para estudar o fenômeno - muitas vezes organizado por redes familiares em um dado espaço e tempo. Em seu estágio inicial o nepotismo ocorre através de uma rede de poder local, espalhando-se pelos poderes executivo, legislativo e judiciário abordados no texto. Além destes, o autor elege os cartórios, os tribunais de contas, o Conselho Nacional de Justiça - CNJ, os tribunais 
eleitorais e os conselhos das estatais para a execução de um detalhado exame do nepotismo no Brasil. Vale ressaltar ainda os fluxogramas apresentados, uma ferramenta primordial para entendimento do fenômeno nas principais esferas de poder do país.

No quarto momento, o nepotismo é retratado no Estado do Paraná a partir da emblemática figura de Aníbal Khury, Deputado Estadual que perpetuou seu poder a partir da segunda metade do século XX na Assembleia Legislativa do Paraná. Articulado, o legado deixado por Khury de clientelismo e patronagem no centro legislativo que leva seu nome é estudado pelo autor. A partir da figura central de Aníbal Khury, Oliveira destrincha o nepotismo no Paraná e a herança do fenômeno no poder legislativo, com os empresários nas relações do poder executivo, enfim, no cenário político paranaense do século XX e início do século XXI.

É a partir deste quarto momento que há uma das mais importantes contribuições do livro: as exatas 62 famílias que comandam o poder (nas diversas ramificações já citadas) no Estado do Paraná dos tempos de província até os dias de hoje. Oliveira conseguiu um grande achado em suas pesquisas ao afirmar categoricamente este número, além de apontar (com riqueza de dados) quem são, como são parentes e onde estão localizados as veias do nepotismo de cada família elencada.

O livro "Na teia do nepotismo" além de preencher a lacuna existente sobre um dos "temas da moda" em relação às discussões sobre a democracia no Brasil (o nepotismo) torna-se um excelente banco de dados compilado sobre o fenômeno, indicando não somente as famílias que seguem tal processo, mas onde estão praticando o nepotismo e qual a relação delas com o poder, em geral. Em um estilo de fácil leitura e compreensão, mesclando muito bem a escrita acadêmica com a possibilidade de expressão para o público em geral, Oliveira traz com o livro uma contribuição fundamental para quem deseja conhecer e pesquisa mais sobre o fenômeno. Por estas considerações, o livro já nasceu como referência bibliográfica primordial para compreender não somente o nepotismo, mas porque as relações de parentesco são essenciais no atual (e anterior, porque não?) modelo político brasileiro. 